\title{
The Writing of the Lagoon Stories
}

Pamela Gordon

\section{(2) OpenEdition}

\section{Journals}

Electronic version

URL: https://journals.openedition.org/ces/8252

DOI: 10.4000/ces.8252

ISSN: 2534-6695

\section{Publisher}

SEPC (Société d'études des pays du Commonwealth)

\section{Printed version}

Date of publication: 1 April 2011

Number of pages: 159

ISSN: 2270-0633

\section{Electronic reference}

Pamela Gordon, "The Writing of the Lagoon Stories", Commonwealth Essays and Studies [Online], 33.2

2011, Online since 18 November 2021, connection on 06 January 2022. URL: http://

journals.openedition.org/ces/8252 ; DOl: https://doi.org/10.4000/ces.8252

This text was automatically generated on 6 January 2022.

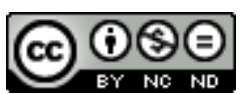

Commonwealth Essays and Studies is licensed under a Licence Creative Commons Attribution - Pas d'Utilisation Commerciale - Pas de Modification 4.0 International. 


\title{
The Writing of the Lagoon Stories
}

\author{
Pamela Gordon
}

\section{EDITOR'S NOTE}

Part of an e-mail from Pamela Gordon to Christine Lorre (8 March 2011) offering additional clarification of the writing history.

1 Frame was around 21 years old when she wrote the Lagoon stories, living in a boarding house in Caversham, Dunedin and working there as a nursemaid caring for some elderly residents. She had some months earlier spent a few weeks in Seacliff hospital, but her serious encounter with the hospital system was not to happen for nearly two more years, and it wasn't initially at Seacliff, it was in Christchurch. The Lagoon stories except for one ("Swans") were all written before Frame's second sister died, and even "Swans" was written more than a year before Frame ever had experimental ECT at the urging of her Christchurch Jungian therapist and became institutionalised as a result.

\section{AUTHOR}

\section{PAMELA GORDON}

Literary Executor, Janet Frame Literary Trust 